\title{
Cashless Policy in Nigeria: Effects, Challenges and Prospects
}

\author{
Obasanmi Jude Omokugbo ${ }^{1}$, Imasuen Osasere Festus ${ }^{2}$ \\ ${ }^{1}$ Department of Economics, Ambrose Alli University, Ekpoma, Nigeria \\ ${ }^{2}$ Department of Business Administration, Delta State University, Abraka, Nigeria
}

Email address:

obasanmijude@gmail.com (Obasanmi J. O.), Imasuenfestus2012@yahoo.co.uk (Imasuen O. F.)

\section{To cite this article:}

Obasanmi Jude Omokugbo, Imasuen Osasere Festus. Cashless Policy in Nigeria: Effects, Challenges and Prospects. Journal of Finance and Accounting. Special Issue: Financial Inclusion, Accounting Perspectives and Development. Vol. 8, No. 1, 2020, pp. 18-23. doi: $10.11648 /$ j.jfa. 20200801.13

Received: December 3, 2019; Accepted: January 13, 2020; Published: February 10, 2020

\begin{abstract}
This study is to investigate the effects, challenges and prospects of cashless policy on the Nigerian Economy. The objectives of the study are to examine: the effects of cashless policy, the challenges of cashless policy and the prospects of cashless policy on the Nigerian economy. The hypotheses of the study are: there are no significant effects of cashless policy on the Nigerian economy: there are no significant challenges of cashless policy on the Nigerian economy, and there are no significant prospects of cashless policy on the Nigerian economy. In carrying out the study, primary data was used which was sourced through questionnaire. A total of one thousand, two hundred questionnaires were passed and after careful monitoring and supervision, there was hundred percent retrieval and used for the analyses. In analyzing the result, simple frequencies, percentages and t-statistics were used to analyze the research hypotheses. From the analyses, it was found that cashless policy has positive effect on the growth of Nigerian economy. Also, respondents were of the opinion that the introduction of cashless banking in Nigeria has increased the cost of e-payment transactions as well as the normal bank charges as they are required to pay for various e-cards aside from indirect payment for technologies acquired to run cashless business venture by the banks. It was concluded that, in as much as the policy is good, there should be a conscious efforts at improving on information and communication infrastructure that will enhance speed in service delivery, internet security framework to check online fraud so that the public can be assured and protected against cyber attacks and fraud.
\end{abstract}

Keywords: Cashless Policy, Challenges, Prospects, E-Commerce, Nigeria

\section{Introduction}

Information technology plays an important role in bringing about sustainable development in every nation. Without an optimal use of information technology, no country can attain a speedy socioeconomic growth and development [1]. The future of all businesses particularly those in the service industry lie in information technology. Infact, information technology has been changing the ways companies, financial and non-financial organizations compete. Information technology is more than computers. It encompasses the data a business creates and uses as well as a wide spectrum of increasing convergent and linked technologies that process such data [2].

Information technology thus relates to the application of technical processes in the communication of data. It is no doubt that information technology can help to reduce transaction costs for banks, which will translate to lower prices for services to customers. Information technology for banks takes different forms which include: computerization of customers' accounts and information storage and retrieval, deposit and withdrawal through Automated Teller Machine (ATM) and networking to facilitate access to accounts from any branch of the bank. Other forms include bio-metrics used in fingerprinting and identification which should dispense the use of passwords or personal identification by customers.

The payments system plays a very crucial role in any economy, being the channel through which financial resources flow from one segment of the economy to the other. It represents the major fundamental of the modern market economy [3]. In recognition of this relevance, the Central Bank of Nigeria $(\mathrm{CBN})$ led by the then Governor, 
Mr. Sanusi Lamido Sanusi initiated a form of payment system that limits individual and corporate daily cash transactions in the banking system. Precisely, the CBN cash limit policy requires that, all cash withdrawals and deposits be set at a daily limit of a maximum of N500,000 while pegging that of corporate entities at $\mathrm{N} 3,000,000$, with penalty fees of $10 \%$ per extra above N500,000 for individual and $\mathrm{N} 3,000,000$ for corporate defaulters respectively. The CBN's reason for the new payment system was attributed to lot of issues affecting the financial system; from check on money laundering and illicit activity, inflation to cost of maintaining an economy predominately cash base. A cashless economy is simply at its prime when all means of payments are carried out without the use of physical cash. Payments will range from a list of options such as cheques, wire transfers, debit and credit cards, online transactions and mobile banking. The advantages of a cashless policy are enormous, from regulating and controlling to securing the financial system of any economy [4]. Furthermore, there are three pivotal roles for the payments system namely; the monetary policy role, financial stability role, and the overall economic role [5].

In the past fifteen years the Central Bank of Nigeria, in collaboration with the Bankers Committee, launched the first major initiative to modernize the payments system. The starting point was to automate the cheque clearing system and making it a veritable platform for development of electronic payment channels. Hitherto, cheques processing and computations of the net settlement position of banks were done manually. The implementation of the new procedures and rules based on Magnetic Ink Character Recognition (MICR) technology revolutionized the cheque clearing system. Consequently, a Centralized Automated Clearing process was established in Lagos clearing zone, whereby with MICR Reader Sorters, necessary information on cheques are captured, built into clearing files and electronically transmitted to the clearing house, from where the net settlement position of participating banks are automatically computed and also electronically transmitted to the Central bank for final settlement. The clearing cycle was subsequently reduced from 5 days to 3 days for local instruments and from 9 days to 6 days in respect of upcountry instruments.

The objectives of the study are to:

1. examine the effect of cashless policy to the Nigerian economy

2. examine the challenges of cashless policy for the Nigerian economy, and

3. investigate the prospects of cashless policy for the Nigerian economy.

This study covers cashless policy adoption in Nigeria. It xrays the issues, challenges faced by customers and banks and the prospects from the adoption of the policy. By the nature of the topic, this study is a literature work. Materials used are secondary (internet, journals, seminars, documentaries, workshops etc) in nature. The primary source data shall be a set of questionnaire.

\section{Literature Review}

\subsection{Conceptual Issues}

Cashless policy is a system that allows individuals to purchase goods or services without the exchange of anything tangible or physical cash. The term money still exists, but it is more in an electronic form than previously. It is same as electronic cash system. Cashless policy or electronic cash is a term becoming more acceptable as the world makes a shift towards a cashless society [6]. Since the 1960's governments and financial institutions globally have made slow, but steady steps towards the goal of a society without cash. The cashless policy is being sold as a more convenient method of payment, and a method of preventing crimes all the way from the robbery of cash from an individual to the extent of money laundering among crime syndicates and cash stockpiling at home by corrupt government officials.

Interestingly, it is not the complete absence of cash, it is an economic setting in which goods and services are bought and paid for through electronic media. Cashless economy is defined as one in which there are assumed to be no transactions frictions that can be reduced through the use of money balances, and that accordingly provide a reason for holding such balances even when they earn rate of return [7]. In a cashless economy, how much cash in your wallet is practically irrelevant. You can pay for your purchases by any one of a plethora of credit cards or bank transfers [8].

Electronic payment systems can be grouped into four broad categories: online electronic cash system, electronic cheque system, smart cards based electronic payment system and online credit card payment system. Each payment scheme has its advantages and disadvantages for the customers and merchants. These payment systems have a number of unique requirements: e.g. security, acceptability, convenience, cost, anonymity, control and traceability. Online credit card payment system seeks to extend the functionality of existing credit cards for use as an online payment tools. This payment system has been widely accepted by consumers and merchants throughout the world, and by far the most popular methods of payments especially in the retail markets [2]. This form of payment system has several advantages, which were never available through the traditional channels of payment. Some of the most important are: privacy, integrity, compatibility, good transaction efficiency, acceptability, convenience, mobility, low financial risk and anonymity. But this payment system has raised several problems before the consumers and merchants.

Irrespective of the convenience offered by this form of payment, it is still fraught with a lot of security challenges. Recent experience has shown that cyber criminals have evolved in response to the current trend for making payments online by engaging in website spoofing. Website spoofing occurs where the cybercriminal masquerades as a known entity by setting up a phony website very similar to the website operated by the entity and attempts to obtain valuable information such as the credit card details from the online consumers [9]. In response to this threat, trusted 
entities in the website community established the Extended Validation (EV) Certificate. An EV certificate is a type of public key certificate issued to a website operator according to a specific set of identity verification criteria. These criteria require extensive verification of the requesting entity's identity by the issuing "trusted third-party" certification authority before the certificate is issued.

Studies carried out by Roth [8], Ochei [10] and Okoye [11] have called attention to particular areas in which the cashless economy will improve the quality of life. These include: speed of transactions: transactions are going to be faster and the problems of long queues are going to be in extinct, improved hygiene: reduction in the carriage of cash (coins and notes) will generally reduce the spread of germs through these means, eradication of problem associated with the counting and sorting cash and it benefits banks and merchants as it increases customer coverage and satisfaction, as it notifies customers about recent activities carried out on their accounts, increases personalized relationship with customers, and fasterdocumentation and tracking of transactions.

However, for a successful running of a cashless economy, the issue of infrastructure must be deliberatelyattended to Lawal [12]. The issue of security is also very serious; the vulnerability of the cashless system to various forms of internet-related crimes must be addressed. Nigeria's low Point of Sales (POS) thickness and poor last mile network constitute huge downsides to the achievement of this policy, the literacy level and level of acquaintance with Information Communication Technology (ICT) among Nigerians high enough. Also, how many Nigerians can use electronic banking services and what infrastructures are there tosupport cashless policy.

\subsection{Theoretical Review}

Theories on cashless policy for now are grossly inadequate. However, the most common explanation is the Technological Acceptance Model. The technological acceptance model was propounded by Fred Davis in 1993. The theory explains how individuals accept new technology and it leads to growth in an economy. In essence, it shows how a user of a proposed technology welcomes and adapts to a new technology. He stated that two beliefs determine the complete acceptance of a technology. These beliefs are perceived usefulness and perceived ease of use. Perceived usefulness is a factor that affects user's acceptance because it is based on how capable the new technology will help improve job performance.

The technology must be capable of producing an advantageous result and must also be able to generate a positive performance. As for perceived ease of use, Davis (1993) defined it as how easy it is for users to make use of new technology. It means that the ability to employ the new technology should be effortless. Prior to the implementation of the cashless policy, Nigeria was a huge cash-based economy. In order to increase the effect of the policy on citizens, the people have to believe that the policy will be easy to use and also result in positive performance thereby, leading to economic growth. E-Banking products must also be reengineered to make electronic payment effortless which will stir the country toward a cashless economy [13].

\subsection{Empirical Review}

Several scholars have attempted to analyze the cashless system or e-banking. However, it becomes clear that few studies present a comprehensive evaluation of cash-less banking implications in developing countries. Most ignore its economic benefits of the equation while some do incomplete examination of its negative implications. This is often due to unreliable panel data for monetary and macroeconomic indicators. In assessing the role of central bank in a cashless policy, Claudia and De Grauwe [14], stressed that central banks gradually lose their monopoly position in the provision of liquidity combined with its subsequent small size which makes it hard to control the short-term interest rates. On the contrary, Marco and Bandiera [15] argued that increased usage of cashless banking instruments strengthens monetary policy effectiveness and that the current level of e-money usage does not pose a threat to the stability of the financial system. However, it does conclude that central banks can lose control over monetary policy if the government does not run a responsible fiscal policy.

Humphery and Berger [16] present one of the earliest attempts to comprehensively estimate the private and social costs for nine separate payment instruments- cash, cheques, credit cards, money orders, Point Of Sale (POS), Automated Clearing House Transfers (ACH), ATM bill payments, Traveler' cheques and Wire transfers. They find that from a social cost perspective, cash is the cheapest payment instrument, followed by ACH, POS and ATM bill payment. From a private perspective, cheques emerge as the cheapest payment method followed by cash, $\mathrm{ACH}$ and POS bill payments. However, the influence of government intervention was prematurely considered as there was no calculation of net benefits of such payments instruments [17].

In recent times, there is a consensus that central banks have the capacity to control the price level. One of the approaches is through controlling money supply (advocated by monetarists) and has led many central banks to implement money-supply-targeting procedures [14]. Although, this study focuses on Nigeria, it is difficult to translate cashless studies from one country to another. Even payments instruments that look similar across countries on the surface may be different due to historical and legal variations [17].

Adu [18] studied the effects of cashless policy on the Nigerian economy with particular reference to how it was kick-started in Lagos. He identified the means of payments (both manual and electronic), positive and negative effects of cashless policy, benefits to the economy and stakeholders, suggestions were made to the Nigerian government on how to curb some of the negative effects and to improve on the implementation of the policy. 


\section{Research Methods}

\subsection{Research Design}

This study adopts the descriptive survey design, which is based on obtaining information from the opinions of the respondents (Bankers and Customers) in-order to determine the issues, challenges and prospects of cashless policy in Nigeria.

\subsection{Population, Sample Size and Sampling Procedure of the Study}

The population of the study consists of all the operators, users and regulators of the cashless policy in Nigeria. The sample was all the Benin City head offices of twenty banks (Commercial and Micro finance) in Nigeria. From each head office, Ten (10) bankers and fifty (50) customers were randomly selected making it a total of one thousand, two hundred $(1,200)$ respondents for the study. These respondents cut across all the cadres of the bank and the customers.

\subsection{Research Instrument}

The instrument adopted is the purposive sampling technique. This is employed because of the nature of the topic of the study. The questionnaire was designed to be able to elicit opinions from respondents. The researchers designed the questionnaire based on the stated objectives of the study. The questionnaire had four sections (A-D). Section A covered personal data while sections B to D were on the objectives of the study. A total of one thousand two hundred $(1,200)$ questionnaires were distributed and after careful monitoring and supervision all were retrieved.

\subsection{Method of Data Analysis}

Frequencies were used and also the T-statistics wasused to analyze the hypotheses of the study. The decision rule is that, if the t-calculated is greater than the table value, then the null hypothesis is rejected, while the alternative hypothesis is accepted and we conclude that there is significant relationship between cashless policy and Nigerian economy.

\section{Data Analysis}

\subsection{Demographic Statistic of Respondents}

Table 1. Sex of the respondent.

\begin{tabular}{llll}
\hline & Male & Female & Total \\
\hline Frequency & 613 & 587 & 1,200 \\
Percentage & 56.5 & 43.5 & 100 \\
\hline
\end{tabular}

Source: Researcher's Field survey 2019

The result of Table 1 indicates that there are more males than females respondents. A breakdown of the result shows that male had 56.5 while female had $43.5 \%$.

Table 2. Age bracket.

\begin{tabular}{llllll}
\hline & $\mathbf{2 1 - 3 0}$ & $\mathbf{3 1 - 4 0}$ & $\mathbf{4 1 - 5 0}$ & $\begin{array}{l}\text { Above } \\
\mathbf{5 0}\end{array}$ & Total \\
\hline $\begin{array}{l}\text { Frequency } \\
\text { Percentage }\end{array}$ & 256 & 473 & 337 & 134 & 1,200 \\
\hline
\end{tabular}

Source: Researcher's Field survey 2019

The result of Table 2 indicates that most of the respondents surveyed are within the age bracket of 31-40 years of age. A breakdown of the result shows that $21-30$ years had $21.33 \%$, $31-40$ years had $39.42 \%, 41-50$ had $28.08 \%$ and above 50 years was $11.17 \%$.

Table 3. Highest Educational Qualification.

\begin{tabular}{|c|c|c|c|c|c|}
\hline & WAEC/NECO & OND/NCE & HND/B.Sc & Masters and above & Total \\
\hline Frequency & 166 & 223 & 635 & 176 & 1,200 \\
\hline Percentage & 13.83 & 18.53 & 52.92 & 14.67 & 100 \\
\hline
\end{tabular}

Source: Researcher's Field survey 2019.

The result of Table 3 indicates that most of the respondents have first degree. A breakdown of the result shows that those with WAEC/NECO had $13.83 \%$, OND/NCE had $18.53 \%$ first degree has $52.92 \%$ and masters and above had $14.67 \%$.
Test of Hypotheses

$\mathrm{Ho}_{1}$ : There is no significant effect of cashless policy on the Nigerian economy.

Table 4. Test Result of Hypothesis 1.

\begin{tabular}{lllll}
\hline Subject & No & \% & T-calculated & Table Value \\
\hline Strongly Disagreed & 797 & 66.42 & & Decision \\
Disagreed & 289 & 24.08 & 23.43 & 9.49 \\
Agreed & 110 & 9.17 & & Reject \\
Strongly Agreed & 4 & 0.33 & & \\
\hline
\end{tabular}

Source: Researcher's SPSS Output. 2019

Since t-calculated is greater than the table value (i.e. $23.43>9.49$ ), then the null hypothesis is rejected, while the alternative hypothesis is accepted and we conclude that there is significant relationship between cashless policyand the
Nigerian economy.

$\mathrm{Ho}_{2}$ : There is no significant challenge of cashless policy on the Nigerian economy. 
Table 5. Test Result of Hypothesis 2.

\begin{tabular}{llllll}
\hline Subject & No & \% & T-calculated & Table Value & Decision \\
\hline Strongly Disagreed & 241 & 20.01 & & & \\
Disagreed & 932 & 77.67 & 18.43 & 8.16 & Reject \\
Agreed & 16 & 1.33 & & & \\
Strongly Agreed & 11 & 0.92 & & \\
\hline
\end{tabular}

Source: Researcher's SPSS Output. 2019

Also, since t-calculated is greater than the table value (i.e. $18.43>8.16)$, then the null hypothesis is rejected, while the alternative hypothesis is accepted and we conclude that there is significant challenge of cashless policy on the Nigerian economy. This is in line with Roth [8] that, the cashless policy in Nigeria has some challenges which need to be addressed if it is expected to fill the identified gaps in the financial sector of the Nigerian economy.

$\mathrm{Ho}_{2}$ : There is no significant prospect of cashless policy on the Nigerian economy.

Table 6. Test Result of Hypothesis 3.

\begin{tabular}{lllll}
\hline Subject & No & \% & T-calculated & Table Value \\
\hline Strongly Disagreed & 319 & 26.58 & & Decision \\
Disagreed & 834 & 69.50 & 27.12 & 9.65 \\
Agreed & 26 & 2.17 & & Reject \\
Strongly Agreed & 11 & 0.92 & & \\
\hline
\end{tabular}

Source: Researcher SPSS Output. 2019

Also, since t-calculated is greater than the table value (i.e. $27.12>9.65)$, then the null hypothesis is rejected, while the alternative hypothesis is accepted and we conclude that there is significant prospect of cashless policy on the Nigerian economy.

\subsection{Discussion of Results}

From the findings as shown in the hypotheses tested, it shows and further confirms the findings of other studies. The introduction of cashless banking in Nigeria has a strong influence on the development of the payment system. However, the introduction of the system involves commitment of huge amount of financial resources on computer technology, telecommunication facilities and electricity. This isin-line with the study ofIzuogu [2]. In spite of the fact that banks have invested heavily in computer technology to drive their operations only few business organisations in Nigeria carry out their financial transactions through automated means, which creates gaps between supply and demand for bank products. This, no doubt, affects the development of cashless banking in Nigeria as discovered by Lawal [12].

In examining the relationship between Nigerian economy and cashless banking, it was established that there is indeed a connection between cashless banking and the economy and this shows that the introduction of the policy would improve Nigerian economy as well as the profit level of Nigerian business men and women. Nevertheless, the policy will affect employment negatively as introduction of automation would automatically reduce number of personnel needed to carry out different financial transactions in the bank. This supports the research findings ofAyodele [19] where he concluded that one of the consequences of cashless system is the gradual replacement of personnel with machines. In otherwords organisations would rather deplore more machines and get few human persons to operate the automated machines.

Most of the respondents are of the opinion that the introduction of cashless banking in Nigeria has increased the cost of e-payment transactions as well as the normal bank charges as they are required to pay for various e-cards aside from indirect payment for technologies acquired to run cashless business venture by the banks. Furthermore, Lawal [12] findings that infrastructural deficiencies such as poor power supply, inadequate communication links, nonprovision of fraud prevention scheme, corruptions and inadequate skilled managers were some of the major problems facing the development of cashless banking in Nigeria was also confirmed in the current study.

\section{Conclusion and Recommendations}

\subsection{Conclusion}

Dynamism in financial system is manifested by the nature and quality of payment products paraded in the system. These products range from common paper money, cheque and cash to electronic payments. Products such as ATM, Smartcard, telephone banking, internet banking etc will, no doubt, reduce or totally eliminate cost of processing cheques. The CBN, commercial banks and other financial institutions are expected to enhance the system through effective banking and monetary policies. To sustain the electronic payment system, strategic measures must be taken to reduce negative effects of the problems identified as obstacles to the smooth functioning of the system.

Above all, Nigerians have a greater role in accepting the cashless banking payment system, making use of it with the belief that it would improve their financial and economic life and boost the image of the country leading to booming economy. High GDP under the cashless banking system 
would attract, encourage and build confidence of foreign investors, tourists and analysts, which would on the long run, lead to further development and improvement of our economy.

\subsection{Recommendations}

To make for the smooth implementation of the cashless system in Nigeria, the following measures are recommended:

1. There is the need to intensify the public enlightenment program about the cashless system so that everybody will be acquainted with the system, since there is a high rate of illiteracy

2. Government should provide uninterrupted power supply and adequate communication link. Power must be improved drastically to accommodate for smooth operations of financial activities,

3. The issue of network failure should be improved if customers are to fully subscribe to it usage.

4. Electronic payment system is capital intensive, therefore banks are encouraged to collaborate among themselves to jointly finance some of the infrastructures and share them amicably. This will help them to share the cost and reduce the initial cost of setting up the electronic banking system.

\section{References}

[1] Taiwo, J. N., Ayo K. O., Afieroho, E. O and Agwu M. E (2017). Appraisal of Cashless Policy on the Nigerian Financial System. Journal of Political Economy 4 (2), 28-47.

[2] Izuogu, C. E. (2012). Enhancing Online Consumer Confidence in the Cashless Economy. Business Day Online, http://businessdayonline.com/NG/index. php/law/cover/34766-enhancing-onlineconsumer-confidencein-the-cashless-economy. Retrieved 23/8/2019.

[3] CBN (2017). Cashless Lagos Implementation: New Cash Policy Stakeholder Engagement Sessions (October). Online: http://www.cenbank.org/cashless/Cashless\%20Lagos\%20Pres entation_November.pdf retrieved 11/10/2019.

[4] Ngango, A., Mbabazize, M. and Shukla J. (2015), E-Banking and Performance of Commercial Banks in Rwanda. A Case of Bank of Kigali. European Journal of Accounting Auditing and Finance Research, Vol. 3 (4), 25-57. Retrieved from http://www.eajournals.org/wp-content/uploads/E-Bankingand-Performance-of-Commercial-Banks-in-Rwanda.pdf on $12 / 4 / 2019$

[5] CBN Website (2013). New Cash Policy, Presentation for the Interactive Engagement Session with Stakeholders on CashLess Lagos, Stakeholder Session-Supermarket Operators.
[6] Basel, C. (2008). Risk Management for Electronic Banking and Electronic Money Activities II, Basel Committee Publications, No. 35 .

[7] Woodford, M. (2013): Interest and Prices: Foundations of a Theory of Monetary Policy. Princeton University Press.

[8] Roth, B. L. (2016). "The Future of Money: The Cashless Economy-Part 1". Extracted fromhttps://www.x.com/.../futuremoney-cashless-economy on October 2, 2019.

[9] Rifat, O. S. (2013). Key Issues in E-Banking Strengths and Weaknesses: The Case of Two Jordanian Banks. European Scientific Journal, 9 (7), 239-263.

[10] Ochei, L. C. (2012). Effective strategies for monitoring and controlling overspending in a cashless society: Lessons for citizenship empowerment. African Journal of Computing \& ICTs, 5 (5): 159-162.

[11] Okoye, P. V. C. and Raymond, E. (2013). An appraisal of cashless economy policy in development of Nigerian economy. Research Journal of Finance and Accounting, 4 (7): 237-252.

[12] Lawal, A. (2012): "Impact of the cashless economic policy on card uptake in the country", Lagos, being a text of speech delivered by the Director, Switching and Processing, Interswitch during a media briefing on the Verve promo. November.

[13] Nwankwo, O. And Eze, O. R. (2013): Electronic Payment in Cashless Economy of Nigeria: Problems and Prospect. Journal of Management Research, 5 (1), 138-151.

[14] Claudia, C. and P. De Grauwe (2001): Monetary Policy in a Cashless Society II, Brussels, CEPR Discussion Study.

[15] Marco, A. and L. Bandiera (2004): Monetary Policy, Monetary Areas and Financial Development with Electronic Money, IMF Working Study, IMF.

[16] Humphrey, D. B. and A. N. Berger (2006): Market Failure and Resource Use: Economic Incentives to Use Different Payment Instruments || ., New York, Monograph Series in Finance and Economics.

[17] Daniel, D. G., R. W. Swartz, and A. L. Fermar, (2014): Economics of a Cashless Society: An Analysis of Costs and Benefits of Payment Instruments \|, AEI-Brookings Joint Center.

[18] Adu, C. A. (2016): Cashless Policy and Its Effects on the Nigerian Economy. European Journal of Business, Economics and Accountancy 4 (2): 81-82.

[19] Ayodele, T. D. (2015), Nigerian Payment Systems through Electronic Banking (EBanking): A Review. International Journal of Transformations in Business Management. 5 (2), 27-33. Retrieved from: http://www.ijtbm.com/images/short_pdf/1434773582_Ayodele _Thomas_3.pdf on 19/8/2019 